\title{
IMPLEMENTATION OF REALISTIC MATHEMATICS EDUCATION BASED ON ADOBE FLASH PROFESSIONAL CS6 TO IMPROVE MATHEMATICAL LITERACY
}

Uba Umbara $^{* 1}$, Zuli Nuraeni ${ }^{2}$

${ }^{1,2}$ STKIP Muhammadiyah Kuningan

\begin{tabular}{l} 
Article Info \\
\hline Article history: \\
Received Nov 13, 2018 \\
Revised June 17, 2019 \\
Accepted Sept 2, 2019 \\
\hline
\end{tabular}

Keywords:

Adobe Flash Profesional CS 6, Mathematical Literacy, RME

\begin{abstract}
Students' mathematical literacy abilities are important to master, especially to formulate mathematical concepts that can be used in everyday life. Mathematical literacy has become an important issue lately to be developed in the study of mathematics learning. However, mathematical literacy has not become the main goal in the implementation of the learning carried out. The purpose of this study was to examine the comparison of students 'mathematical literacy skills with Adobe Flash Professional CS6-based RME learning with conventional learning and to examine the comparison of improvement in students' mathematical literacy skills with Adobe Flash Professional CS6-based RME learning with conventional learning. The research method used in this study was quasi-experimental with the design of a non-equivalent control group design. The results of the two research hypotheses were accepted. It is possible that the increase in students' mathematical literacy skills is triggered by the Adobe Flash Professional CS6-based RME learning which in the implementation of learning always focuses on self regulated learning.
\end{abstract}

Copyright @ 2019 IKIP Siliwangi. All rights reserved.

\section{Corresponding Author:}

Uba Umbara,

Departement of Mathematics Education,

STKIP Muhammadiyah Kuningan,

Jl. R.A. Moertasiah Soepomo No. 28 B, Kuningan, Jawa Barat 45511, Indonesia

Email: uba.bara@upmk.ac.id

How to Cite:

Umbara, U., \& Nuraeni, Z. (2019). Implementation of realistic mathematics education based on adobe flash professional CS6 to improve mathematical literacy. Infinity, 8(2), 167-178.

\section{INTRODUCTION}

One of the goals that students need to achieve in order to obtain deep and meaningful literacy in mathematics learning is to understand the mathematics they learn through constructing students' abilities regarding various mathematical concepts. Constructing these capabilities, can be done if students have the ability to read and write mathematical symbols known as mathematical literacy abilities. Mathematical literacy skills help individuals to recognize that mathematics plays a role in every aspect of life. Mathematical literacy is an individual's capacity to formulate, employ and interpret mathematics in a variety of contexts. It includes reasoning mathematically and using mathematical concepts, procedures, facts and tools to describe, explain and predict phenomena. It assists individuals to recognise the role that mathematics plays in the world 
and to make the well-founded judgements and decisions needed by constructive, engaged and reflective citizens (OECD, 2017).

By looking at this, literacy can be placed as a very important ability, not only in mathematical learning but also mathematical literacy further in life. Mathematical literacy helps one to understand the role or usefulness of mathematics in everyday life. In a discussion, mathematical literacy is not limited to the ability to apply quantitative aspects of mathematics but involves mathematical knowledge in a broad sense (De Lange, 2003). This action has mandated the teacher to think differently about what learning means and understanding mathematical concepts for students to align more closely with mathematical literacy (NCTM, 2000). Meanwhile, Gallimore and Tharp (Draper, 2002) stated in the most general sense that the ability to read, write, speak, calculate, reason, and manipulate symbols, concepts of verbal and visual as a form of literacy must be taught in school. In daily life, the equalization of students and teachers' perceptions of the importance of mathematical literacy is so important to do (Venkat, 2010). Thus, we consider someone to be mathematicsally illiterate, if he is unable to read and write. This mathematical literacy is the impact of demands that encourage people to survive under the culture and civilization they have in an area. Mathematical literacy refers to the ability and knowledge of students to take and apply the knowledge and abilities acquired from the classroom into their reallife understanding and experience in situations involving mathematical concepts (Sumirattana, Makanong, \& Thipkong, 2017).

In particular, mathematical literacy can be interpreted as the ability of an individual to understand and use mathematics in daily life activities. The subject that is specifically driven by the application of mathematics in life is at the core of a discussion of mathematical literacy that must be owned by someone (Julie, 2006). In this connection, someone who studies mathematics is required to have and develop the ability to solve mathematical problems, especially those related to daily activities. Some activities that can encourage mathematical literacy are (1) mathematical and mathematical concepts of reasoning, (2) recognizing the roles played by mathematicians in the world, (3) making reasonable decisions and decisions, (4) solving problems set in pupils of the world life context (Sandström, Nilsson, \& Lilja, 2013).

In mathematics, students are expected to build knowledge by reading, analyzing, and writing mathematical texts (for example, numbers, symbols, graphics) to be considered mathematical literacy (Siebert \& Draper, 2012). Mathematical literacy has become a serious OECD study through PISA which began in 2000. Nevertheless, Rico (Sáenz, 2009) explained that PISA is often not directly related to the mathematics curriculum taught in schools, but revolves around the functional model of mathematics learning by developing competencies that are directly related to real world. This concept is then seen to be highly related to realistic mathematical concepts that are focused on the application of contextual mathematics (Gravemeijer, 1994).

Furthermore, Larochelle \& Bednarz (Colwell \& Enderson, 2016) integrates literacy into mathematics, and promotes the vision of constructivist learning. This ability can help students formulate mathematical concepts in solving problems in their daily lives in a structured and systematic way. However, even though it has been stated that mathematical literacy skills are very much needed by students, in reality this field of ability is still not fully controlled by students. One effort that can be implemented in improving students 'mathematical literacy skills is learning Realistic Mathematics Education (RME) which is supposed to be able to generate students' enthusiasm in learning so that in the end it is expected to be able to improve their literacy skills. The main idea of RME learning is that students must be given the opportunity to rediscover mathematical concepts. 
Therefore, RME is a potential model that integrates open problem-based learning, collaborative learning, error analysis and problem solving in the real world (Hidayat \& Iksan, 2015). RME can be understood as an approach that emphasizes social processes, because learning is based on the principle of mutual respect for students' ideas in completing mathematical problems (Umbara, 2015). Furthermore, as a form of development of RME learning, in this study computer-assisted RME learning will be used using Adobe Flash Professional CS6 software. There are many benefits to using flash animation in learning especially in helping students understand mathematics more meaningfully, connecting mathematics with the real world, visualizing, and understanding the importance of mathematics (Salim \& Tiawa, 2015).

The use of animated courseware is seen as very useful to see concrete examples of abstract concepts that require a deep understanding of mathematics learning (Pesonen, 2003). Learning material compiled using Adobe Flash software is expected to facilitate students in understanding contextual problems presented in learning. Previous research was conducted the mathematical thinking process based on the RME approach assisted by VBA Excel helps students bridge the horizontal mathematization process towards vertical mathematization mathematical formations (Fitriani, Suryadi, \& Darhim, 2018). Furthermore, Salomon states that integrating ICT in education has the motivation to support students' ability to explore constructive thinking that enables them to have the ability to transcend cognitive limitations that they might not be able to do before (Lim et al., 2003).

Integrating ICT in learning is seen as being able to develop a culture of thinking by involving students with problems that are challenging but meaningful personally through the use of the world conceptually and the learning culture of the students themselves. However, one challenge is to find methods that can increase the effectiveness of learning in learning and teaching through ICT (Cañas, Novak, González, \& Hammond, 2004). Learning with RME based on Adobe Flash Professional CS6 is expected to be able to improve mathematical literacy skills significantly because it is based on the process of providing learning experiences to students and is not limited to the process of transferring knowledge and knowledge with display of contextual problems that are not only imagined by students but real for students. Based on the background above, research aims to review whether mathematical literacy of students with RME based on Adobe Flash Professional CS6 is better than students who obtain learning with conventional learning and assessing the Increasing of mathematical literacy of students who apply the RME based on Adobe Flash Professional CS6 learning better than students who obtain learning with conventional learning.

\section{METHOD}

The research method chosen was quasi-experimental research, because the subjects were not randomly grouped but the researchers accepted the condition of the subject as a minimum. The design used in this study is the design of non-equivalent control groups. In this experimental design there were two sample classes, the pretest, the different treatment and the posttest. The sample in the first class is an experimental class that uses RME learning based on Adobe Flash Professional CS6. Meanwhile the second class as a control class that gets learning using ordinary learning. The existence of this control class is a comparison, to what extent changes occur due to the treatment of the experimental class. The design diagram of this study is as follows (Ruseffendi, 2005). 


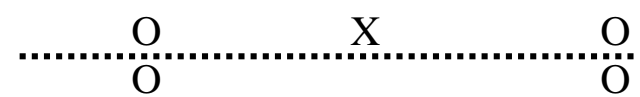

Information :

$\mathrm{O}$ : Pretest and posttest in the form of tests of mathematical literacy skills

$\mathrm{X}$ : The treatment uses the RME learning based on Adobe Flash Professional CS6.

--- : Subjects are not randomly selected

The population in this study were all eighth grade students of SMP Negeri 3 Kuningan totaling 284 students. The sampling technique is done by using purposive sampling technique. The reason for choosing the sample was purposive sampling because the two groups were not actually randomized, only based on the existing class. The sample chosen from the class VIII-A students was used as the experimental class and class VIII-C which was used as the control class with the number of students in both classes amounting to 65 students. The instrument that will be used in the research is a mathematical literacy test. To provide an objective assessment, the criteria for scoring the test questions for mathematical literacy skills researchers adopted from Quasar General Rubric (Maryanti, 2012), as shown in Table 1.

Table 1. Scoring Guidelines Mathematical Literacy

\begin{tabular}{|c|c|c|c|}
\hline \multirow[b]{2}{*}{ Score } & \multicolumn{3}{|c|}{ Student Response } \\
\hline & $\begin{array}{l}\text { Mathematical } \\
\text { Knowledge }\end{array}$ & Strategy & Communication \\
\hline 0 & $\begin{array}{l}\text { Does not show } \\
\text { Literacy concepts } \\
\text { and mathematical } \\
\text { principles of the } \\
\text { problem. }\end{array}$ & $\begin{array}{l}\text { Using irrelevant information, } \\
\text { it fails to identify an } \\
\text { approach that can be used to } \\
\text { answer questions, copy some } \\
\text { problems without any } \\
\text { solution being given. }\end{array}$ & $\begin{array}{l}\text { Ineffective communication, } \\
\text { words do not describe the } \\
\text { problem, not completely } \\
\text { illustrate the problem. }\end{array}$ \\
\hline 1 & $\begin{array}{l}\text { Very little shows the } \\
\text { literacy of } \\
\text { mathematical } \\
\text { concepts and } \\
\text { principles, one fails in } \\
\text { mathematical terms } \\
\text { and the majority of } \\
\text { calculations are } \\
\text { wrong. }\end{array}$ & $\begin{array}{l}\text { Using irrelevant information, } \\
\text { failing to identify an } \\
\text { important part, the strategy } \\
\text { used is incorrect, the facts } \\
\text { provided are incomplete, } \\
\text { difficult to identify or not } \\
\text { systematic. }\end{array}$ & $\begin{array}{l}\text { Some parts are explained but } \\
\text { not complete and do not pay } \\
\text { attention to the important } \\
\text { parts of the problem, } \\
\text { explanations are less and } \\
\text { difficult to understand, the } \\
\text { concepts given do not } \\
\text { represent problems or are not } \\
\text { clear (difficult to interpret) }\end{array}$ \\
\hline 2 & $\begin{array}{l}\text { Understanding some } \\
\text { mathematical } \\
\text { concepts and } \\
\text { principles, there are } \\
\text { still many mistakes } \\
\text { in calculations. }\end{array}$ & $\begin{array}{l}\text { Identify the important parts } \\
\text { of the problem, but only } \\
\text { show a little Literacy about } \\
\text { the relationship between the } \\
\text { two parts, showing the facts } \\
\text { of the calculation process but } \\
\text { not complete and not } \\
\text { systematic. }\end{array}$ & $\begin{array}{l}\text { Some of the sections } \\
\text { explained have led to } \\
\text { problems, but some } \\
\text { explanations are still } \\
\text { ambiguous or unclear, the } \\
\text { mathematical concepts } \\
\text { presented are not precise or } \\
\text { unclear, the arguments } \\
\text { provided are incomplete and } \\
\text { the explanation does not enter } \\
\text { the basic logic of the problem. }\end{array}$ \\
\hline
\end{tabular}




\begin{tabular}{|c|c|c|c|}
\hline \multirow[b]{2}{*}{ Score } & \multicolumn{3}{|c|}{ Student Response } \\
\hline & $\begin{array}{l}\text { Mathematical } \\
\text { Knowledge }\end{array}$ & Strategy & Communication \\
\hline 3 & $\begin{array}{l}\text { Most literacy } \\
\text { concepts and } \\
\text { mathematical } \\
\text { principles, the use of } \\
\text { terms and } \\
\text { mathematical } \\
\text { notation are close to } \\
\text { true, outline } \\
\text { calculations are } \\
\text { correct but there are } \\
\text { some calculations } \\
\text { that are still wrong. }\end{array}$ & $\begin{array}{l}\text { Using relevant information, } \\
\text { identifying a number of parts } \\
\text { and showing in general the } \\
\text { relationship between these } \\
\text { parts, giving clear facts in the } \\
\text { calculation and systematic } \\
\text { process, the answers are } \\
\text { close to true. }\end{array}$ & $\begin{array}{l}\text { The responses given are } \\
\text { close to complete, with clear } \\
\text { explanations and } \\
\text { descriptions, mathematical } \\
\text { concepts are presented in } \\
\text { full, answers are generally } \\
\text { communicated effectively so } \\
\text { that they are easily } \\
\text { understood by others, } \\
\text { provide supporting } \\
\text { arguments and the } \\
\text { arguments given are } \\
\text { reasonable but there are } \\
\text { some small parts that are } \\
\text { omitted and not explained }\end{array}$ \\
\hline 4 & $\begin{array}{l}\text { Showing correct } \\
\text { literacy concepts and } \\
\text { mathematical } \\
\text { principles, the use of } \\
\text { terms and } \\
\text { mathematical } \\
\text { notation is correct, } \\
\text { calculation and use } \\
\text { of complete and } \\
\text { correct algorithms. }\end{array}$ & $\begin{array}{l}\text { Using relevant information, } \\
\text { identifying all the important } \\
\text { parts and showing the } \\
\text { general relationship between } \\
\text { these parts, describing the } \\
\text { systematic approach and } \\
\text { strategy, presenting facts } \\
\text { clearly in the calculation } \\
\text { process, correct and } \\
\text { systematic answers. }\end{array}$ & $\begin{array}{l}\text { Providing complete and } \\
\text { clear responses, } \\
\text { unambiguous explanations } \\
\text { and descriptions, } \\
\text { mathematical concepts are } \\
\text { presented in full, effectively } \\
\text { communicated so that they } \\
\text { are easily understood by } \\
\text { others. Give a strong } \\
\text { argument where the } \\
\text { argument is reasonable and } \\
\text { complete. }\end{array}$ \\
\hline
\end{tabular}

Furthermore, at the stage of processing research data, the procedure is carried out as follows: (1) Give a score on student answers according to alternative answers and scoring system used; (2) Make a table of the pretest and posttest students scores of the experimental class and the control class; (3) Calculate the average test score for each class; (4) Calculate the standard deviation to find out the distribution of groups and show the level of variance in the data group; (5) Conduct normality tests to determine the normality of the pretest, posttest and N-gain scores as a whole using the Saphiro-Wilk test; (6) If the data is not normally distributed, then the Mann-Whitney nonparametric test can be directly carried out; (7) If the data meets normal assumptions, then the variance homogeneity test can be carried out using the Lavene Statistics test. If the variance of the two classes is not homogeneous, a t test can be done directly; (8) After a normal and homogeneous assumption is fulfilled, then it can then test the two average differences (t-test) using Compare Mean Independent Samples Test; (9) Next to test the difference between two data gain averages, in this case between the data gain of the experimental class and the data gain of the control class. If the data is normally distributed and homogeneous, then to see whether there are differences in the increase in mathematical literacy skills viewed from KAM, a two-way ANOVA Test can be carried out. If the data is not normally distributed, 
it can be continued with the Kruskal-Wallis Test. Meanwhile, the statistical test used to determine the interaction between the factors of the learning model provided with the category factors of increasing students' mathematical literacy skills can be carried out by two-way ANOVA test using the General Linear Model Univariate Analysis.

\section{RESULTS AND DISCUSSION}

\subsection{Results}

After processing the pretest and posttest score data on the aspects of mathematical comprehension ability in the experimental and control groups, descriptive statistics were obtained as shown in the following Table 2.

Table 2. Descriptive statistics Mathematical Literacy Capability Score

\begin{tabular}{ccccccccccc}
\hline \multirow{2}{*}{ Test } & \multicolumn{4}{c}{ Experiment Class } & \multicolumn{6}{c}{ Control Class } \\
\cline { 2 - 11 } & $\mathbf{N}$ & $\mathbf{X}_{\min }$ & $\mathbf{X}_{\max }$ & $\overline{\boldsymbol{x}}$ & $\mathbf{S}$ & $\mathbf{N}$ & $\mathbf{X}_{\min }$ & $\mathbf{X}_{\max }$ & $\overline{\boldsymbol{x}}$ & $\mathbf{S}$ \\
\hline Pretest & 31 & 44 & 72 & 52.26 & 4.12 & 34 & 32 & 76 & 54.97 & 10.74 \\
Postest & 31 & 60 & 92 & 75.10 & 7.48 & 34 & 35 & 92 & 66.24 & 12.89 \\
\hline
\end{tabular}

Table 2 presents students' mathematical literacy descriptive statistics. The statistical data states that students' abilities are obtained through pretest and posttest consisting of: number of subjects $(\mathrm{N})$, lowest score $\left(\mathrm{X}_{\min }\right)$, highest score $\left(\mathrm{X}_{\max }\right)$, average $(\overline{\boldsymbol{x}})$ and standard deviation ( $\mathrm{Sd}$ ). Based on table 5.4 the average value of the experimental class pretest is 52.26 and the control class average value is 54.97. The control class has an average greater than the experimental class. Meanwhile, the experimental class posttest score was 75.10 and the control class was 66.24. The experimental class has a higher average value than the control class.

The initial analysis carried out in this study was to conduct a pretest score analysis. Analysis of the pretest score was done to see the students' initial abilities or find out whether the difference in the average score of the pretest students in the experimental group and the control group was done using the Mann-Whitney non parametric test, because based on the normality and homogeneity tests that had been done previously, it was known that one the data are distributed abnormally but are homogeneously distributed, so that the similarity test of the average pretest score is done. Testing the hypothesis with a one-way test with $\alpha=0.05$ with the testing criteria is accept $\mathrm{H}_{0}$, if Asymp.Sig (1-tailed)> $\alpha$, besides $\mathrm{H}_{0}$ is rejected. The test results of the difference in post-test average mathematical literacy ability are shown in Table 3.

Table 3. Test Results Differences in Average Post-Score Mathematical Literacy Ability

\begin{tabular}{lr}
\hline & Test Statistics $^{\text {a }}$ \\
& Post Mathematical Literacy $^{-}$ \\
\hline Mann-Whitney U & 287.000 \\
Wilcoxon W & 882.000 \\
Z & -3.175 \\
Asymp. Sig. (2-tailed) & .001 \\
\hline
\end{tabular}

a. Grouping Variable: Research Class 
Table 3 show the Asymp. Sig (2-tailed) value for the posttest data of students' mathematical literacy ability is 0.001 . If taken $\alpha=0.05$ then Asymp.Sig ( 1 -tailed) $<\alpha$ so that $\mathrm{H}_{0}$ is rejected. In conclusion, one research hypothesis was accepted, that: students' mathematical literacy skills using RME based on Adobe Flash Professional CS6 were better than students who used conventional learning.

To determine the significance of the difference in the average of the two data classes, a two-way analysis of variance (ANOVA) was conducted. This analysis was conducted to see the direct effect of two different treatments given to students 'mathematical literacy abilities, as well as the interaction between the learning approaches used to the students' ability categories. The results of the calculation of variance analysis test using the General Linear Model (GLM) - Univariate carried out at a significance level of $5 \%(\alpha=0.05)$. The results of the analysis are shown in the following Table 4.

Table 4. Analysis of Gain Variance in Mathematical Literacy

\begin{tabular}{lccccc}
\hline \multicolumn{1}{c}{ Source } & $\begin{array}{c}\text { Type III Sum } \\
\text { of Squares }\end{array}$ & df & Mean Square & F & Sig. \\
\hline Corrected Model & $1.576^{\mathrm{a}}$ & 5 & .315 & 10.876 & .000 \\
Intercept & 3.695 & 1 & 3.695 & 127.480 & .000 \\
KAM & .690 & 2 & .345 & 11.898 & .000 \\
Model & .479 & 1 & .479 & 16.516 & .000 \\
KAM * Model & .018 & 2 & .009 & .309 & .735 \\
Error & 1.710 & 59 & .029 & & \\
Total & 11.588 & 65 & & & \\
Corrected Total & 3.286 & 64 & & & \\
\hline
\end{tabular}

a. R Squared $=.480$ (Adjusted R Squared $=.436)$

Table 4 show the value of Fcount $=16.516$ with a significance level (Sig.) is 0.000 smaller than $\alpha=0.05$. Therefore, the null hypothesis is rejected, meaning that the increase in mathematical literacy skills of students who get learning using the RME based on Adobe Flash Professional CS6 is better than students who get learning using conventional approaches. In other words, it can be concluded that the second hypothesis is accepted.

\subsection{Discussion}

The results showed that students with RME learning based on Adobe Flash Professional CS6 had higher average mathematical literacy abilities than students who used conventional learning. This result is possible because through this learning students are able to learn independently, the teacher as a facilitator who provides clues and suggestions in group discussions conducted by students when students feel difficulty in understanding and resolving contextual problems so that students get an understanding of the mathematical concepts better. RME seems to be a promising teaching approach that meets Indonesia's needs to improve mathematics teaching (Lestari \& Surya, 2017). On the other hand, the rapid development of ICT supports the development of multimedia learning, one of which can be done using Adobe Flash. The effort aims to improve the quality of learning better. In this ever-changing era, schools must maximize the contribution of new technologies that can be implemented in teaching and learning (Psycharis \& Kallia, 2017). Computer technology devices as learning tools have great potential if they can be utilized in the learning process (Suartama, 2010). 
RME learning based on Adobe Flash Professional CS6 makes students active in mathematical learning and can rediscover mathematical concepts in their own way. RME was a movement to reform mathematical education, so it was not only a mathematical learning method, but also an attempt to carry out social transformation (Sembiring, 2010). Mathematical learning with Adobe Flash Professional CS6-based RME is learning that takes advantage of contextual problems that are easily understood by students and students are given the widest opportunity to solve problems given independently according to their initial knowledge. This activity means that students are given the opportunity to describe, interpret and look for appropriate strategies. Meanwhile, these activities did not occur in mathematical learning using conventional learning.

In general, the learning process that occurs in the experimental class is in accordance with the guidelines and criteria and characteristics of RME learning. This is reflected in the active process of students in discussions, asking questions, answering problems in more than one way, explaining and displaying the results of their work in front of the class. Student activities during the learning process seem to run smoothly, even though at first the students have not been able to adapt optimally. This is understandable because the learning process carried out is somewhat different from the learning they have been used to. RME which is carried out based on the principle of constructivism provides space for students to provide their abilities in carrying out mathematical activities. The final benefit of this adaptation is an active and fun math class based on constructivist understanding by accommodating student needs and involving communication between students and teachers (Draper, 2002).

The enthusiasm of students in learning is seen when they begin to understand the contextual problems related to daily activities, they really feel the aspects of the usefulness of mathematics. this corresponds to the mathematical literacy aspects that are trying to be developed. In mathematics, to improve mathematical literacy, change is needed to focus on communicative and language-centric activities to hone students' mathematical literacy skills (Colwell \& Enderson, 2016). In this study, RME learning based on Adobe Flash Professional CS6 was seen to be able to influence the way students learn so that they can improve their learning achievement. The use of RME increases students 'mathematical achievements and encourages students to actively participate in mathematics teaching and learning, but students' attitudes towards mathematics are still the same as conventional learning (Zakaria \& Syamaun, 2017). Collaboration between RME as an approach and the use of adobe flash in bringing ICT-based learning into its own advantages that complement each other. This is consistent with a similar study which provides the conclusion that animated content developed using Macromedia flash students is far better than conventional approaches to high school students' mathematical connection skills (Rohendi, 2012), and make mathematics learning more active and fun (Chotimah, Bernard, \& Wulandari, 2018).

The influence of the learning method in question is primarily on the independence of learning by context-based learning in learning. Furthermore, if you look at the results of the research that has been stated, it shows that RME Learning based on Adobe Flash Professional CS6 is significantly better in improving students' mathematical understanding skills compared to learning using conventional learning. RME learning based on Adobe Flash Professional CS6 provides an interesting learning experience for students, because the problems presented in learning are relevant to their daily activities, technology support allows students to easily explore the concepts being studied. From this perspective, the use of technology in learning has a central role (Mills, 2003). specifically, that new knowledge can be possessed by students through a systematic and ongoing process with the help of animation media used in learning (Taylor, Pountney, \& Baskett, 2008). 
RME learning based on Adobe Flash Professional CS6 designed by displaying animation applications seems to provide significant changes in learning. In other words, this technology-based learning has great potential in learning especially helping in the development of mathematical concepts and improving student achievement (Kurz, Middleton, \& Bahadir Yanik, 2004). In addition, ICT has a role in helping visualize abstract mathematical concepts (Oktavianingtyas, Salama, Fatahillah, Monalisa, \& Setiawan, 2018). This concept is in line with the theory of cognitive development, where children at the formal-operational stage have the capacity to use abstract hypotheses and principles both simultaneously and sequentially (Umbara, 2017). On the other hand, the basic reason that can be stated is that in the implementation of learning in the control class that uses conventional learning, the teacher only provides informative learning. So that the learning carried out tends to be passive and the ability of students to develop mathematical concepts cannot be explored to the maximum.

Duranti \& Goodwin (Mkhwanazi \& Bansilal, 2014) states that when context problems are raised, it is usually debated that focus events cannot be properly understood, interpreted correctly, or explained in a relevant way, unless someone looks beyond the event itself to another phenomenon (eg cultural settings, speech situations, share the background assumptions) where the event is pinned, or alternatively that the features of the lecture itself use certain background assumptions that are relevant to the organization of the next interaction. Overall, based on the implementation of RME learning based on Adobe Flash Professional CS6, students' mathematical literacy abilities appear simultaneously because students are trained to reason and solve problems. Two factors suggested as the development of literacy skills centers are mathematical reasoning and problem solving (Venkat, Graven, Lampen, Nalube, \& Chitera, 2009).

\section{CONCLUSION}

Based on the results of the study, obtained several research conclusions, including mathematical literacy of students with RME based on Adobe Flash Professional CS6 are better than students who obtain learning with conventional learning and increasing of mathematical literacy of students who apply the RME based on Adobe Flash Professional CS6 learning better than students who obtain learning with conventional learning.

\section{ACKNOWLEDGEMENTS}

We are very grateful to the DRPM Ministry of Research, Technology and Higher Education Republic of Indonesia for funding this research grant, family, work colleagues and partners who helped carry out this research.

\section{REFERENCES}

Cañas, A. J., Novak, J. D., González, F. M., \& Hammond, A. K. N. (2004). Synchronous Collaborative Concept Mapping Via ICT: Learning Effectivness and Personal and Interpersonal Awareness. Acessado Em, 28, 8-9.

Chotimah, S., Bernard, M., \& Wulandari, S. M. (2018). Contextual approach using VBA learning media to improve students' mathematical displacement and disposition ability. In Journal of Physics: Conference Series, 948(1), 12025. 
Colwell, J., \& Enderson, M. C. (2016). “When I hear literacy”: Using pre-service teachers' perceptions of mathematical literacy to inform program changes in teacher education. Teaching and Teacher Education, 53, 63-74.

De Lange, J. (2003). Mathematics for literacy. Quantitative literacy: Why numeracy matters for schools and colleges, 80, 75-89.

Draper, R. J. (2002). School mathematics reform, constructivism, and literacy: A case for literacy instruction in the reform-oriented math classroom. Journal of Adolescent \& Adult Literacy, 45(6), 520-529.

Fitriani, N., Suryadi, D., \& Darhim, D. (2018). The students'mathematical abstraction ability through realistic mathematics education with vba-microsoft excel. Infinity Journal, 7(2), 123-132.

Gravemeijer, K. (1994). Educational development and developmental research in mathematics education. Journal for Research in Mathematics Education, 25(5), 443-471.

Hidayat, R., \& Iksan, Z. H. (2015). The Effect of Realistic Mathematic Education on Students' Conceptual Understanding of Linear Progamming. Creative Education, 6(22), 2438.

Julie, C. (2006). Mathematical Literacy: Myths, further inclusions and exclusions. Pythagoras, 12(1), 62-69.

Kurz, T., Middleton, J., \& Yanik, H. B. (2004). Preservice Teachers Conceptions of Mathematics-Based Software. International Group for the Psychology of Mathematics Education, 3, 313-320.

Lestari, L., \& Surya, E. (2017). The Effectiveness of Realistic Mathematics Education Approach on Ability of Students' Mathematical Concept Understanding. International Journal of Sciences: Basic and Applied Research (IJSBAR), 34(1), 91-100.

Lim, C. P., Teo, Y. H., Wong, P., Khine, M. S., Chai, C. S., \& Divaharan, S. (2003). Creating a conducive learning environment for the effective integration of ICT: Classroom management issues. Journal of Interactive Learning Research, 14(4), 405-423.

Maryanti, E. (2012). Peningkatan literasi matematis siswa melalui pendekatan metacognitive guidance. Universitas Pendidikan Indonesia.

Mills, J. D. (2003). A theoretical framework for teaching statistics. Teaching Statistics, 25(2), 56-58.

Mkhwanazi, T. W., \& Bansilal, S. (2014). Mathematical literacy teachers' engagement with contextualised income tax calculations. Pythagoras, 35(2), 1-10.

NCTM. (2000). Principles and standards for school mathematics. Reston, VA: National Council of Teachers of Mathematics.

OECD (2017), PISA 2015 Assessment and Analytical Framework: Science, Reading, Mathematic, Financial Literacy and Collaborative Problem Solving, PISA, Paris: OECD Publishing.

Oktavianingtyas, E., Salama, F. S., Fatahillah, A., Monalisa, L. A., \& Setiawan, T. B. (2018). Development 3D Animated Story as Interactive Learning Media with 
Lectora Inspire and Plotagon on Direct and Inverse Proportion Subject. In Journal of Physics: Conference Series, 1108(1), 12111.

Pesonen, M. E. (2003). Experiments on using interactive web-based mathematics problem sets based on dynamic geometry applets. In Mathematics and Natural Science Education in the North-East of Europe: History, Traditions, Contemporary Issues. Proceedings of the Sixth Inter-Karelian Conference. Sortavala, Russia, 11, p. 14.

Psycharis, S., \& Kallia, M. (2017). The effects of computer programming on high school students' reasoning skills and mathematical self-efficacy and problem solving. Instructional Science, 45(5), 583-602.

Rohendi, D. (2012). Developing e-learning based on animation content for improving mathematical connection abilities in high school students. International Journal of Computer Science Issues (IJCSI), 9(4), 1.

Ruseffendi, E. T. (2005). Dasar-dasar penelitian pendidikan dan bidang non-eksakta lainnya. Bandung: Tarsito.

Sáenz, C. (2009). The role of contextual, conceptual and procedural knowledge in activating mathematical competencies (PISA). Educational Studies in Mathematics, 71(2), 123-143.

Salim, K., \& Tiawa, D. H. (2015). The Student's Perceptions of Learning Mathematics using Flash Animation Secondary School in Indonesia. Journal of Education and Practice, 6(34), 76-80.

Sandström, M., Nilsson, L., \& Lilja, J. (2013). Displaying Mathematical Literacy--Pupils' Talk about Mathematical Activities. Journal of Curriculum and Teaching, 2(2), 5561.

Sembiring, R. K. (2010). Pendidikan Matematika Realistik Indonesia (PMRI): Perkembangan dan Tantangannya. Journal on Mathematics Education, 1(1), 11-16.

Siebert, D., \& Draper, R. J. (2012). Reconceptualizing literacy and instruction for mathematics classrooms. Adolescent Literacy in the Academic Disciplines: General Principles and Practical Strategies, 172-198.

Suartama, I. K. (2010). Pengembangan mutimedia untuk meningkatkan kualitas pembelajaran pada mata kuliah media pembelajaran. Jurnal Pendidikan Dan Pengajaran, 43(3).

Sumirattana, S., Makanong, A., \& Thipkong, S. (2017). Using realistic mathematics education and the DAPIC problem-solving process to enhance secondary school students' mathematical literacy. Kasetsart Journal of Social Sciences, 38(3), 307315.

Taylor, M. J., Pountney, D. C., \& Baskett, M. (2008). Using animation to support the teaching of computer game development techniques. Computers \& Education, 50(4), 1258-1268.

Umbara, U. (2015). Efektivitas pembelajaran realistic mathematic education (RME) terhadap kemampuan representasi matematis siswa. JUMLAHKU: Jurnal Matematika Ilmiah STKIP Muhammadiyah Kuningan, 1(1).

Umbara, U. (2017). Psikolgi pembelajaran matematika (melaksanakan pembelajaran matematika berdasarkan tinjauan psikologi). Yogyakarta: Deepublish. 
Venkat, H. (2010). Exploring the nature and coherence of mathematical work in South African Mathematical Literacy classrooms. Research in Mathematics Education, 12(1), 53-68.

Venkat, H., Graven, M., Lampen, E., Nalube, P., \& Chitera, N. (2009). 'Reasoning and reflecting'in mathematical literacy. Learning and Teaching Mathematics, 2009(7), 47-53.

Zakaria, E., \& Syamaun, M. (2017). The effect of realistic mathematics education approach on students' achievement and attitudes towards mathematics. Mathematics Education Trends and Research, 1(1), 32-40. 